\title{
The meaning and making of childhoods in kinship care - young adults' narratives
}

Jeanette Skoglund, Amy Holtan \& Renee Thørnblad

Published online: January, 2018

\begin{abstract}
This article draws on interviews with 26 young adults (15 women and 11 men, aged 19-29) who grew up in long-term kinship care in Norway, and explore how they portray their childhoods. Our starting point is that the foster child status provide cultural and public narratives, images and positions for the young adults to employ when interpreting childhood experiences. The question we ask is how this status is made relevant in the production of childhood narratives. Doing this, we seek to gain insights into how the formal aspect of kinship care can influence on childhood understandings. Based on how childhood experiences are (re)constructed and how the young adults position themselves and their foster parents in their narratives, we have constructed four ways of portraying childhoods in kinship care, as: normal, supported, struggling and neglected. The article clarifies the criteria for constructing the different types of childhood, and discusses how the foster child status is made relevant in each type.
\end{abstract}

Keywords: Kinship care, childhood, foster child, narratives, clientisation, normality 


\section{Introduction}

Childhood reminiscences constitute an important part of modern life stories (Gullestad, 2004). One of many childhood contexts in which adults look back on is kinship foster care, here defined as ' the care provided to children and youth in state custody by relatives ' (Hegar \& Scannapieco, 1999, p. 1). In this article, we explore such childhoods through the narratives of young adults who grew up in this context.

Growing up with relatives is not a new phenomenon. Throughout history, upbringing by relatives have been solutions in the private sphere in various cultures to meet challenges such as parental death, poverty, teenage pregnancies and parents' substance abuse (Andresen, 2006). What is new, however, is the institutionalisation of kinship care - as a category and a service within child protection systems (CPS).

In Norway, which provides the context for the present study, kinship care has equal status to other foster care placements, and is regulated according to current legislation. CPS has the formal responsibility for the child, who becomes a client of the welfare state and is ascribed status, according to the terminology found in child protection legislation, as a foster child. Their grandparents, aunts and uncles are formally redefined as the child's foster parents. This process, where situations in the family are translated into 'system language' and adjusted to conform to the already established categories of the welfare state, is central to the process of clientisation (Järvinen \& Mik-Meyer, 2003, 10). This means that not only are people's problems categorized - they are also transformed into recognizable problems and dealt with according to the relevant category. 'At-risk children' is one example of institutionally-rooted problem identities within CPS, often associated with risks of poor life outcomes or social deviance (Thørnblad \& Holtan, 2011, 51).

When a child is taken into care, the aim is to prevent any further neglect and to provide him or her with what is considered a 'good' childhood. To reach this goal, all kinship 
care placements are formalized through the foster care contract (The Ministry of Children and Equality 2010). The contract represents an agreement between the foster parents and CPS, and involves a structuring of relationships within the family and between the family and CPS. The contract is mutually revocable, and financial compensation is a part of the arrangement. The foster parents' fulfilment of the contract is evaluated through controlled visits from CPS, along with other types of monitoring. Today, foster children are also included in this process, giving them power to evaluate their childhoods and their foster parents.

The regulation and control of childhood and family life builds on and reflects a human rights discourse along with a psycho-social risk discourse (Pupavac, 2001). In this article, we ask how the formal aspect of kinship care can influence on childhood understandings among young adults who grew up in this context. By this, we mean that the foster child status opens up a framework in which to interpret childhood experiences, but can close off others. Our understanding of framework resemble what Goffman (1974) has called frames, here understood as ' schemata of interpretation' that enable and restrict the organisation of experiences and situations in particular ways (ibid., 21). Essential components of what can be called the foster child frame include assumptions about children in foster care as a vulnerable, at-risk population. In Scandinavia, an alternative cultural image is the 'dandelion child' who, due to personal characteristics did well in life despite growing up as a foster child. Another aspect of this frame of interpretation is the rights of the child (Archard, 1993), which has also influenced on the foster child status. Seen through the foster child frame, the question as to whether or not ones rights have been fulfilled becomes dominant. Challenges in childhood can be interpreted as something out of the ordinary and characterized according to the terminology found in CPS (e.g. as neglect). If, when and how the foster child status is made relevant has gained little attention in foster care research. 
It is against this background that we analyse young adults' narratives of childhoods in kinship care. Childhood in this article is not restricted to a specific age, but to upbringing more generally, including adolescence. Our data consist of qualitative interviews with 26 young adults, aged between 19 and 29, who grew up in long-term kinship care. We emphasise that we do not regard these narratives as factual recollections of childhood experiences, but approach them as social products and interpretive devices(Lawler, 2002). Rather than being interested in what childhood was really like for these young adults, we turn our attention to what childhood memories are selected, how these are presented and how the foster child status is made relevant in their narrative work. We are, in other words, interested in how the young adults seek to portray their childhoods. Following Bamberg's (1997) advice on performativity, we pay attention to how the narrators position themselves and other relevant characters in their stories. Doing this, our aim is to show variation in terms of how childhood in kinship care can be portrayed by young adults who grew up in this context.

\section{Kinship care and previous research}

In Norway, 11,771 children lived in foster care by the end of 2016, making it the most used out-of-home care placement. Among these children and adolescents, 2893 (24.6\%) lived in foster care with aunts, uncles, grandparents or other relatives as foster parents (Statistics Norway 2017). The use of kinship care placements has not always been preferred within CPS (e.g.: Egelund, 1997; Hessle \& Vinnerljung, 1999; Sinclair, Baker, Lee, \& Gibbs, 2007). In the Scandinavian countries, this can be related to the adoption of social work approaches in the 1960s that sought to prevent negative social heritage (Jonsson, 1969). In this multigenerational perspective, it was assumed that the parent(s) of the child who needed a new home also had experienced neglect or abuse. Hence, the child's grandparents were deemed unfit as caregivers (Thørnblad 2010). Over the last decades, such attitudes have changed and 
kinship care has emerged as the preferred choice for placement in Western Europe, the United States, Australia and New Zealand (Ainsworth \& Maluccio, 1998; Broad, 2004; Hegar \& Scannapieco, 1999). In Norway, this shift became evident in 2004 when childcare authorities were given new guidelines, stating that they 'should always consider whether someone in the child's family or close network could be appointed foster parents' (The Ministry of Children 2003).

In a review of the US literature, (Cuddeback, 2004) found that kinship caregivers are more likely to be single women, older, less educated and poorer than non-kinship caregivers. Similar findings have been found from the Norwegian context (Holtan \& Thørnblad, 2009). Nevertheless, it's important to highlight the diversity of family forms and relationships within the category kinship care (Skoglund \& Thørnblad, 2017). These are practiced within various cultures and societies alongside other family forms, giving way to a range of different childhood experiences. In this article, we address variation in childhood experiences through the ways in which childhood is portrayed among young adults who grew up in this context. We have not found any study with similar focus. Furthermore, compared to an extensive body of literature on former foster children who grew up in non-kinship care placements (e.g.: Stein \& Munro, 2008) only a few studies can be found that focuses explicitly on former foster children in the kinship care literature (e.g.: Del Valle, Lázaro-Visa, López, \& Bravo, 2011). This article is a contribution to this research area.

Commonly perceived benefits of growing up in kinship care is that it can secure children a familiar environment, reduce the trauma children may experience when moving in with strangers, and enable a sense of continuity in children's lives (Gibbs \& Müller, 2000). Qualitative studies from the British and Nordic context indicate that kinship care arrangements allow for childhood experiences that are perceived as normal. This claim is based on findings from qualitative interviews showing that children, adolescents and young 
adults perceive themselves, their family arrangement, and upbringing as ordinary, despite having what some would consider unusual backgrounds (Burgess, Rossvoll, Wallace, \& Daniel, 2010; Egelund, Jakobsen, \& Steen, 2010; Thørnblad \& Holtan, 2011). With that said, there are also aspects of growing up in kinship care that can be complex. One issue, which is often emphasised in the kinship care literature, is parental contact. Studies have indicated that children who grow up in kinship care experience more contact with their birth parents (Harden et al. 2004). Qualitative studies that includes children's perspectives give a mixed picture of experiences related to this issue. While many children regard their parents as important to them, the same children also find parental contact challenging or in some cases problematic (Burgess et al., 2010; Kiraly \& Humphreys, 2013; Knudsen \& Egelund, 2011). Acknowledging that many children who grow up in kinship care experience complex and challenging issues does not signify an intention on our part to contribute to debates as to whether kinship care is beneficial or not. Discussions about the 'quality' or ' effects' are available elsewhere (e.g.: Winokur, Holtan, \& Batchelder, 2014). Rather, our concern here is about how such issues are (re)constructed in adulthood.

\section{Data and Method}

This article is based on data from 26 open-ended interviews conducted between 2014-2015, involving 15 women and 11 men, aged between 19 and 29. All of the interviewees had, as children, been placed in foster care according to the Norwegian Child Welfare Act, sections 4-12, concerning custody. Based on the young adults' own statements, these interventions were in most cases related to parental alcohol and drug abuse, and in some cases parental psychological problems or the death of birth parents. The interviewees and/or their birth parents and foster parents participated in Holtan's longitudinal national study 'Childhood in Foster Care with Relatives'. Recruitment was conducted through the foster 
parents, who were asked to give us the information we needed to send out information sheets to the children, now adults. Prior to this, the study was approved by the Norwegian Data Inspectorate.

The interviewees in the study were asked to talk about three topics: the background to why they grew up in foster care, their childhoods and adolescence, and their life today. In each interview, follow-up questions were adjusted to be relevant to each interview. The interviewees chose the locations of the interviews, which lasted between 60 and $180 \mathrm{~min}$, with an average of $90 \mathrm{~min}$. In the information sheet and before each interview the interviewees were informed that they could withdraw from the study at any time. A post-interview debriefing followed each interview. All the interviewees expressed that the interview had been a positive experience.

All interviews were digitally recorded with the permission of the respondent, and later fully transcribed. In the quotes from the interviewees, any information that could threaten the anonymity of the interviewees was changed or left out. For instance, all the names that appear in the analysis are fictive. The interviewees' occupations have also been changed, but reflect the status of the young adults' original occupations.

Using the language of CPS, the interviewees' upbringings can be described as longterm placements, meaning that they had lived most of their childhoods in kinship care. The majority (21) of the interviewees had lived permanently with their grandparents or aunts and/or uncles from the age of three or younger; four were placed in kinship care between the ages of four and six; and one at the age of eight. While most of the interviewees' placement story can be described in terms of stability, a more comprehensive analysis adds a more complex picture. Before being placed in foster care, two of the participants had lived one year in an orphanage. If we look at the participants' family and placement history after being placed in kinship care, two of the interviewees had, as teenagers, moved to another foster 
home outside the family. One had changed foster home from her grandmother to her aunt around the age of 10 . Four of the interviewees also had experienced staying a short time at institutions for therapy. This means that some of the young adults in this study not only had experiences of growing up in kinship care, but also of other types of care. Finally, it can be added that four interviewees had been adopted by their relatives after turning 18 .

At the time of their interviews, two still lived at home with their foster parent(s). One of the interviewees had moved back in with her grandmother to save money. The other interviewees lived alone, with partners or friends. Six of the interviewees received aftercare, meaning that they were formally still foster children. In Norway, aftercare refers to various types of support received from CPS after turning 18. With the foster child's consent, their time in care can be extended until the age of 23 . Two of the interviewees were planning to receive aftercare in order to receive financial support when starting their university education and six had received aftercare until they had turned 23.

Explorations of their life situation, educational level and employment show that the interviewees represent a diverse group of young adults. Three women and one man had children. Four had a history of drug abuse and had attended or were still attending programmes or therapy to cope with their addiction. As for their highest level of education, for eight it was primary school, 16 had completed secondary education, one had a bachelor's degree and one had a master's degree. Twelve young adults said that work was their main occupation, while seven stated that it was higher education. Two of the interviewees were on maternity leave and four were unemployed. The four who did not work received different types of welfare support, as did six other young adults. When we look more closely at these financial and educational variables, we see that those with primary school as their highest educational level were the ones receiving social support, who were working part time or who 
did not work at all. This group constitutes approximately one third of the sample, while two thirds are more similar to the average Norwegian in their twenties, based on such variables.

\section{Analysis}

In our analysis, we employed the logics of the abductive research strategy (Blaikie, 2007). This means that we moved away from the young adults' 'lay descriptions' of their childhoods to more technical descriptions of such childhoods (Ibid., 91). In the following, we give an account of this process.

During the first round of analysis, we relied on open coding, closely reading each transcript to identify patterns in the material. Throughout this process, it became clear that the young adults recalled many similar issues from childhood, especially when talking about challenges and problems. However, it also occurred to us that they spoke about their experiences in diverse ways. Examples of topics include being bullied at school and having to relate to their parents' substance abuse or psychological problems.

Another important lead at this stage were the opinions expressed by the interviewees about their childhoods, as they were often contradictory. For example, one started the interview by saying that her aunt and uncle had given her a good childhood. Nevertheless, she consistently continued to display her childhood as a struggle, giving little space for any positive aspects of her upbringing.

Inspired by narrative analytical perspectives (e.g.: Bamberg, 1997; Riessman, 2008) we changed our focus and asked: What types of childhoods are the participants seeking to portray? To answer the question we paid attention to how and why particular events were storied, and how the interviewees positioned themselves and other relevant characters. In this process, we also explored when and how the foster child frame was employed. Emotions (e.g. 
anger, indifference, appreciation) were also analysed, both those displayed during the interview and the ones recalled from the past. Throughout this process, always interrogating the evidence and comparing interviews, we were able to detect differences and similarities in ways of portraying childhood. Based on this analytical process, we constructed four ways of portraying childhood, as: normal, supported, struggling and neglected. To clarify, these categories are based on our interpretations of how the young adults portrayed their childhoods. They are archetypical constructs, or what can be termed 'second-order constructs' (Schutz, 1963). The aim of these categories is to bring out variation and patterns in terms of how childhood in kinship care can be narratively (re)constructed years later, by young adults who grew up in this context.

\section{The normal childhood}

The story about the normal childhood is not about a particular type of childhood, a 'better' childhood, nor is it about normality per se. Rather, the normal childhood in this article, is more about what is said and what is not said, and what the young adult considers to be useful information in a context such as the interview setting. To get a better understanding of what this means, we start with the interview with Einar, a 20-year-old university student. When asked to talk about his childhood, he struggled. Einar had agreed to participate in the study because his aunt and uncle, Anna and Tom, had encouraged him to do so, believing the research to be important. Because of his birthparents' substance abuse, Einar had lived with his aunt and uncle on a permanent basis since he was two years old. Prior to it becoming a foster care placement, Anna and Tom had a close relationship with Einar's birth parents, and had been involved in taking care of Einar as a baby. Einar considered his family to include Anna and Tom, whom he called mum and dad, and his cousins, whom he called his siblings. He had some contact with his birth father, but considered him to be a background figure in the 
family context. As Einar said, he did not have much to tell - he had just had a normal upbringing in a normal family.

If we understand Einar correctly, he did not have any stories he thought would fit the interview context. During the interview, Einar said that he did not know whether his information was boring, and asked the interviewer what she was really looking for in these interviews. The interviewer replied that she was interested in exactly what he was telling her. He smiled and asked: 'So you're not looking for sunshine stories or horror stories?'Einar's question reveals his knowledge about dominating narratives about growing up in foster care. We see these stories in books, in the media and in research. Einar is aware of their existence and has access to them, but rejects them. Our interpretation is that they do not fit his interpretation of his own childhood.

Markus (27) also rejected similar available narratives. When talking about his job as an engineer, he was asked what he thought was the reason for his success, compared to the overall statistics of previous foster children. He answered:

Well, I don't really think it's DESPITE anything, and I think that's exactly what's important here ... Some are given those opportunities, while others are NOT (Markus, 27).

What Markus is rejecting here is the story about 'making it ', despite being a foster child. He does not identify as a dandelion child, the cultural image often used on former foster children who do well in adult life. Like, Einar, Markus emphasized normality in various ways in the interview, but during the first part, information appeared that challenged this. Markus was asked to talk about why he came to live in foster care with his aunt and uncle on his mother's side. Before his first birthday, his mother had died and his paternal aunt and uncle became his 
primary caregivers. Due to an 'unstable environment for child-rearing', his maternal aunt and uncle 'stepped in' and became his foster parents instead. About his mother's death, Markus said that it was 'more like a course of events' which he knew of, but didn't have a connection to, making him only 'indirectly affected'. About the neglect he had experienced as a child after his mother's death, Markus said that he didn't have much memory of that period either: 'It was such a long time ago (...) I don't know if I should have an opinion about it, it just wasn't an ideal environment'. Markus clearly toned down the significance of problematic past events, presenting them as facts that he did not give much thought to. We asked him to amplify further. Marcus hesitated, and said:

So, just to sort of make it a bit more tidy ...Well, I grew up with Hanna being my sister, even if biologically speaking, she isn't. I've never given it much thought. I suppose that's good, really (Markus, 27).

By 'setting the record straight', Markus is taking control over the direction of the story by showing how he wants to portray his family, himself and his childhood.

For Markus and the other interviewees portraying the normal childhood, the foster child status is reduced to a formality. They did not identify with the foster care terminology, and referred to their foster parents as mum and dad and their foster siblings as brothers and sisters. Nevertheless, like all the participants in the study, they grew up as foster children in foster care involving visits from CPS, financial compensation and so on. The stories told about these visits are constructed in a specific way, like drips of irritation in an otherwise normal childhood. Einar expressed it like this: 
I've never actually gone around thinking about living in a foster home. I've always just thought that I live at home, that I have an extra dad on the side. So in a way it's just like a normal upbringing with a twist - with some ... irritation or disturbance from the child protection service who kept coming and asking if I was all right. And I always was. I had a really good childhood, so there haven't been any real problems. The story of my childhood isn't particularly exciting, even if it was in a foster home (Einar, 20).

In Einar's account, visits from CPS during childhood are regarded as unnecessary, disturbing his own understanding of the normal childhood. As such, he portrays it as an intrusion, which he and his family could have done without.

\section{Challenging childhoods}

Unlike Markus and Einar and a few others portraying the normal childhood, most of the interviewees had 'stories to tell'. These stories often revolved around challenging and problematic events and relationships from their childhoods. In the following paragraphs, we show three ways of presenting such challenging childhood experiences.

\section{The supported childhood}

The interviewees portraying the supported childhood expressed that they were glad they grew up within the family - they had experienced what they considered a good childhood. Some expressed the importance of 'knowing one's roots'. Similar to those portraying the normal childhood, these young adults also emphasized normality when talking about family relationships. However, they gave fuller descriptions of challenges they had met 'along the way', and combined them with narratives of support from family members. 
One of the interviewees who portrayed her childhood in this way was Emilie (20), a university student who grew up with her grandparents due to her mother's drug abuse. During a conversation about her mother's struggles, Emilie was asked why she thought she had done so well in life. She said:

Grandma and grandad are amazing people. They have always talked very openly about everything, so there have never been any secrets. I have always been given information about my mum, and I'm sure that this has contributed to me being confident in myself and the decisions I make. They have been really supportive, they have set goals for me, expected things from me. But of course there have also been difficult periods ... for several years my mum was SO bad with the drugs that it was impossible to see her. I had birthday presents and Christmas presents sent by post. And that was obviously quite sad, because my friends celebrated their birthdays with their mums - and mine just sent stuff by post. But it's just - well, we got through that as well.

In Emilie's account, the difficult experiences are centred around the actions of her birth mother. Here, Emilie talks about the challenge of not having her mother around for important events such as Christmas and birthdays. Later in the interview, she also talked about the challenges she experienced in connection with her mother's presence at family events, both in her childhood and adult life. Another difficult issue Emilie has had to deal with since her teenage years is her mother's repeated pregnancies. Two of her siblings also grew up with her grandparents, but her youngest sister grew up in foster care outside the family. Stories about the 'irresponsible' and 'uncontrollable' mother and the challenges that occurred because of this are not only found in Emilie's interview - it was a theme in many of the others as well. In 
other interviews, it was the birth father who represented challenges, and in some cases both. This was especially the case for parents with a history of drug abuse, but also in cases of psychological problems. What is important here is not each separate event, but how they are storied - as challenges, which, as Emilie says, have been met and worked out together with her grandparents, within the family.

Among the interviewees who portrayed the supported childhood, their foster parents are not just presented as 'the most important parents' - they talked about them with great respect and often described them in ways that give associations to heroes or the phrase "the rock in my life'. Using the term 'foster parents', however, is quite misleading. Apart from one example, it was predominantly the women - the grandmothers and the aunts - who were given such positions in the narratives. One of many examples of such portrayals of women can be found in the interview with Marianne (22), a part-time receptionist. One of the challenging issues in Marianne's narrative was her restricted relationship with her sister who had lived in foster care outside the family. According to Marianne, her sister's foster parents did not want them to have a close relationship. Once during her teenage years, they had agreed to let Marianne come and visit, but had changed their minds at the last minute:

For my part it was quite disappointing, but my aunt managed to compensate for it by saying she would take the day off so we could go shopping! So we went, and had a lovely day to compensate for the disappointment that I wasn't able to see my sister. She really put herself out for me. I mean, I know that she cares about me, and she does everything so that I will be okay. She - well, if I do something bad, I obviously get shouted at and that. But she has always been there for me (Marianne, 22). 
In Marianne's account, her aunt is portrayed as a heroine in the sense of 'saving the day' and her rock in terms of never giving up on her, despite how difficult Marianne was as a child. These stories were told with displays of deep emotions. One of the interviewees started crying when talking about all the support her grandmother had given her. She said they were happy tears: 'I just don’t know what I would do without her'.

In childhoods portrayed as supported, not only foster parents are given important roles. Other significant people include friends, siblings, relatives, stepmothers, and in some cases birth parents. The presence of CPS is to a large degree portrayed as an inconvenience or reduced to a source to financial resources. An example of the latter is Sandra's case. She was supposed to be adopted by her foster parents when she turned 18, but when she found out that she could get support for college from CPS by prolonging her foster child status, she and her foster parents decided to wait until she turned 23. Emilie (20), on the other hand, wanted to be free of the foster child status as soon as possible. If she needed help after turning 18, she would rather ask her grandparents. She put it like this:

As soon as I turned 18 and they started talking about after care and that - nope, done with that! Thanks for everything, but goodbye! They only came because they HAD TO, because of the law. And I knew that I would get financial support from my grandparents. They have supported me like most normal parents do - even after the kid has turned 18 you kind of ... help them if you HAVE TO (Emilie, 20)

\section{The struggling childhood}

A third way of portraying childhood in kinship care in our material we have called the struggling childhood. To get a better understanding of what this involves we start with Frode, a 25-year-old car mechanic. Frode grew up with his paternal aunt and uncle from the 
age of five, due to the alcohol addiction of his birth parents. Similar to those portraying the supported childhood, he said that the decision to place him in foster care within his family had been the right thing to do. He was grateful for growing up with his aunt and uncle, to know his family members and his 'family story'. When asked to describe his childhood, he said the following:

My childhood - it was very up and down, because of [my birth parents'] alcoholism. But I grew up in secure circumstances. I was looked after. A lot of stuff still happened though. When I was seven, my mum died. That was a bit of a downturn. And then, six months later, my uncle also died. And there were many conflicts between my foster parents and my dad, they sort of argued a lot, with me there, right in the middle. Yeah, it was quite hard. I also have a brother in another foster home who I don't know ... But ... I got through it (Frode, 22).

Frode describes his childhood as periods of ups and downs, but the positive aspects of his childhood are given scant space - it is the problems and challenges which dominate. These problems are conveyed in a specific way, as 'lists of struggles'. Frode lists the difficult events he encountered in his childhood and adolescence as follows: His mother dying, his uncle dying, conflicts between birth father and foster parents, and not knowing his brother. Another example of 'lists of struggles' can be found in the interview with Ingrid (21), a part-time waitress who also grew up with her aunt and uncle. The problems in Ingrid's childhood evolve around several issues: Being bullied for many years in school, her physical disability, the alcohol addiction of her birth mother and her birth father's absence. Ingrid brought the issues together like this: 
Statistically speaking, thinking about the bullying, my mum being a periodic drunk and my dad being absent and, you know, the medical conditions I have - I should really not be in a very good place. But, well, I don't know - I feel that I am a very positive person, and it has been a great help that I have made a real effort, that I have dealt with it the way I HAVE done (Ingrid, 21).

At first sight, the continuous emphasis on struggles in childhood and adolescence can be interpreted as a form of victimhood. Closer explorations of how the interviewees position themselves in their stories give reason to believe that they do not seek to be understood as victims. As both Frode and Ingrid state after listing their struggles, they see themselves as having managed to 'pull through'. Based on this interpretation it is reasonable to say that the struggling childhood resonate more closely with narratives of survival and the cultural image of the dandelion: it went well despite all the trouble which had occurred during their upbringing. Trude (28), who was unemployed at the time of the interview, expressed it like this:

I had quite a difficult childhood. I was bullied from age four to ten, and ... well, I feel very vulnerable at times ... But they called me a "dandelion child", because despite all kinds of adversity I always got through it. Just like a dandelion squeezing through the paving stones in the spring (Trude, 28).

This understanding of their upbringing sets them apart from those conveying the normal and the supported childhood, where it was because of their upbringing that it has gone so well. As such, the struggling childhood relates more closely to dominating stereotypes attached to the foster child status. 
Another important difference lies in how the foster parents are portrayed. In the struggling childhood and adolescence, it is not the foster mother who is given the role as heroine. Rather, it is they, themselves - their personal characteristics - that 'got them through it'. The interviewees portraying childhood this way often confirmed their resilience through what others had told them, from child welfare practitioners to family members. Thus, 'the struggling childhood' is not about working it out within the family, but about them as individuals - as children and adolescents overcoming adversity.

\section{The neglected childhood}

The interviewees portraying the neglected childhood were the only ones who expressed that they should not have grown up where they did. They did agree that their birth parents were not able to raise them, but they were of the opinion that they should have grown up in other foster homes. They gave various accounts of childhood neglect to support this view, ranging from lack of shielding from birth parents to lack of emotional support. Their narratives were all constructed in a specific way, i.e. as needs that their foster parents had not met during their childhood and adolescence. Here the foster child status was made especially relevant and they spoke from the position of 'children with rights'.

One of the interviewees who portrayed his childhood and adolescence as neglected was Anders (26), an economist who lived with his maternal grandparents from the age of $3-$ 18. Most of Anders' family members were alcoholics, including his birth parents and his aunt and uncle, and he described his family as 'extremely dysfunctional'. His grandparents, whom he grew up with, along with one uncle, were the only people who did not have a drinking problem. He had never had any contact with his family on his father's side. In his early $20 \mathrm{~s}$, Anders had been diagnosed with depression and anxiety, and since then he had seen a therapist regularly. Through therapy, it had become clear to him that he was scared during much of his upbringing due to visits from his family members, including his birth parents. Using a bear cave analogy, Anders expressed the fear he felt as a child: 
It was a bit like living in a bear cave or something. For example, when my dad and my uncle came to visit - the fear I felt then, it was a bit like - being in the woods and suddenly encountering a bear. What you do then is that you - first you think, "I wonder if there's anything here I can use to defend myself with - a stone or something like that" - and then you sort of start running. That's how it felt being with the family, and I had no idea - I thought that what I felt was normal, that it was like that for everybody ... I just thought that was life (Anders, 26).

In Anders' narrative, his childhood is portrayed as a dangerous place: he looks for a way to defend himself from his family members, but he is trapped and has nowhere to go. To get a better understanding of himself Anders had also gained access to files, recorded by CPS during his fifteen years in foster care. When asked what he had found out he said:

Anders: $\quad$ That they [his family] are incredibly dysfunctional, and that I have been seriously traumatised. First of all I should never have been placed in foster care with them. You know - here is a family where three out of four people are deeply dysfunctional - and then the child protection services put me in a foster home with carers who are clearly a major cause of this (...) I think I should have been placed in a family where I could get away from them all, so that I didn't have to develop any kind of connection with them and instead would have been able to forge healthy relationships.

Searching through his files, Anders concludes that he should never have been placed with his grandparents - the same people who had raised his dysfunctional birth mother and aunt. 
Another interviewee who concluded along similar lines is Frederik (25), a technician. Frederik grew up with his grandparents from the age of two. His birth father had never been in his life, and his mother was an alcoholic. As a teenager, Frederik also started drinking heavily, which turned into an addiction. At the time of the interview, Frederik had been sober for four years and had regularly attended group therapy with other addicts. Here, he had scrutinized his childhood, trying to understand the roots of his and his mother's problems. Frederik had the following theory as to why they both had gone down the same path:

I think that if there had been someone I could have talked to, and sort of opened up to, things might have been a bit different ... Because it's just like it was with my mum because I grew up in the same place as she grew up - in a place where we didn't talk about feelings, so it's a bit like that. And that's one thing I feel is wrong with living with relatives, that the same family system sort of just repeats itself. Both in a good way and a bad way (Frederik, 25).

During the interview, Frederik emphasized that his grandparents had also showed him love and affection. What they had failed to do was to support him the right way, to talk about feelings. Frederik interprets this as the same mistake they had made with his birth mother, giving him the same destiny as her.

The foster mother has a central place also among those who portrayed the neglected childhood. However, here, she is not a heroine, but displayed as the one responsible for their misery. Uncles and grandfathers who have functioned as foster fathers are positioned in the background: 
They always told me that I had such a good childhood, always manipulating me. They said all sorts of stuff....or my aunt did - not my uncle, he doesn't say anything doesn't have a backbone. Probably lost in when he married her [his aunt] (Axel, 21).

Finally, it is worth noting that those who portrayed childhood this way appeared to be in some sense closer to their childhood experiences. By this, we mean that they did not just reflect upon the past, but the past was a central issue occupying them in the present. Going through childhood in therapy is an example of this. Frederik gave another example. He said that he planned to invite a few family members over for dinner to confront them about his childhood. This included his two aunts and one uncle, not his grandparents. He wanted them to know how difficult it had been for him, and that they should have interfered in ways that could have given him a better childhood.

\section{Discussion}

In this article, we have explored childhood narratives of young adults who grew up in kinship care and constructed four ways in which childhood can be portrayed: as normal, as supported, as struggling and as neglected. Although a heterogeneous group with diverse childhood experiences, they were all ascribed a foster child status as children - an institutional identity from which they could not escape until the age of 18 . While only a few (6 of 26) of the interviewees were formally still foster children, they all had access to interpret their childhoods through what we in this article have termed the foster child frame. In the normal and the supported childhood, the foster child frame is not applied. Rather, the two ways of portraying childhood builds on an underlying understanding of normality. Here, the foster child status is reduced to a formality, financial matter or an inconvenience. As such, these two 
types are in accordance with research showing that childhood and family relationships in kinship care can be understood as normal among those who grow up this way (Egelund et al., 2010; Thørnblad \& Holtan, 2011). The two ways of portraying childhood also adds to this research as they give deeper insights into what normality can mean or how normality is expressed in the (re)construction of childhood experiences.

The normal childhood is a way of portraying childhood in opposition to contemporary understandings of growing up in foster care - one that was nothing out of the ordinary. However, our findings indicate that conveying normality this way can be a difficult task, especially when interviewed as a former foster child. For example, some of the interviewees who portrayed the normal childhood in our study were careful to tone down the significance of childhood experiences that could challenge the normality they wanted to convey. One can therefor say that although the foster child status is rejected, the status can be a struggle to keep away in particular contexts.

The supported childhood is constructed in relation to challenges experienced in childhood and the young adults' subjective opinion of their adult life situation. As we have showed, this is the story about how it went well because of ones upbringing. While challenging childhood experiences is central to the supported childhood, they are not presented as unique, but as family issues. Some of the interviewees who portrayed the supported childhood in our study related their childhood experiences to those of their childhood friends who were adopted, whose parents were divorced or other family arrangements and situations where friends did not grow up in nuclear families. In other words, they saw their childhoods as a part of the modern childhood experience where children grow up in a range of different family arrangements, not as deviating from it.

While the normal and supported childhood correspond with previous research, this article also sheds light on how childhood can be portrayed when understood as deviating from 
what it should have been like - as struggling or as neglected. It is within these two types that the foster child status can be said to be made relevant in the (re)construction of childhood experiences. Similar to the supported childhood, they are both constructed in relation to challenges experienced in childhood and the young adults' subjective opinion of their adult life situation. The struggling childhood further resembles the supported childhood because it is also a story about how it went well. However, the young adult who portrays the struggling childhood does not see this as a result of one's childhood, but despite it. He or she positions his or her childhood self as vulnerable, marginalised or at-risk. This way of portraying ones childhood self is reminiscent of foster children often described in the foster care literature and close to contemporary understandings of foster children in general. The neglected childhood, on the other hand is not about how it went well. Rather, it consists of stories of blame and of victimhood - about neglect resulting in inevitable negative outcomes in adult life. In the neglected childhood, the young adults evaluate childhood from a rights perspective. Through the foster child frame, childhood is constructed as a stage where childhood needs and rights have not been fulfilled. From this perspective, the arrangement they grew up in is not so much displayed as family, but as a service - the wrong type of service. Interestingly, the interviewees in our study concluded in similar lines with the multi-generational perspective mentioned earlier in the article, also called negative social heritage (Jonsson, 1969). To them, their life situation today would have been better if they had been placed in foster care outside their family, not within the 'dysfunctional' environment that their birth parents grew up in.

Based on the relationships between how childhood is portrayed and when the foster child frame is applied it might be argued that the sadder the tale the more relevant the foster child status becomes. To employ the foster child frame is an expression of clientisation (Järvinen \& Mik-Meyer, 2003, 10). An important question, then, is what leads to sad tales what makes some young adults talk about challenges in childhood as examples of neglect, 
whilst others do not. Without ambitions to give causal explanations, the empirical data used here can provide important insights to these questions. If we compare how childhood is portrayed with how family relationships are displayed among the young adults, we see the contours of a pattern. At one end of the spectrum, we find young adults displaying strong family relationships and a strong sense of belonging, through to family being displayed as dysfunctional and/or broken. A related issue is the question of social resources and the ability of kinship care families to overcome challenging issues. As we showed in the analysis of the supported childhood, challenges are constructed as having been met within the family. The young adult portraying the struggling childhood has also overcome such challenges, however, this is not due to family members, but to their own personal characteristics. In the neglected childhood, on the other hand, difficult issues are not dealt with or overcome by anyone. The different ways of constructing challenging childhood experiences indicate that it is not so much whether or not challenges occur, but how and if they are interpreted as having been addressed and overcome. Furthermore, our analysis give reason to believe that present life situation plays a central role for the (re)construction of childhood experiences. As showed above, the supported, the struggling and the neglected childhood are all constructed around their present life situations. From this angle, one could argue that the adults' 'outcome' would be a key factor in understanding how childhood is portrayed. However, based on normative criteria for a successful adulthood, we find interviewees in the struggling childhood who would score just as high or low as those portraying the neglected childhood. For example, two of these interviewees were unemployed and undergoing rehabilitation for drug abuse. However, they consistently portrayed themselves as having done well in adult life. This does not mean that life situation is not important for how childhood is portrayed, but that a person's interpretation of life situation can be just as important as variables such as education and 
financial situation. Such interpretations do not necessarily correspond to the variables most commonly used to evaluate outcomes in adult life (e.g.: Gypen et al. 2017).

Finally, this study adds to previous research showing that kinship care is often gendered (Holtan \& Thørnblad, 2009). Not only is it primarily women who assume the responsibility for relative's children, they also have central positions in many of the young adults childhood narratives. The grandmothers or aunts who function as foster mothers today might one day be portrayed as heroines by their former foster children. Others, however, might be held responsible for causing neglected childhoods resulting in inevitable negative outcomes in the children's adult lives. Hence, the different ways of portraying childhood is not only important for young adults who grew up in kinship care - it is also important for their former foster parents. Hopefully, our findings may inspire other researchers in the field to explore the meanings and making of childhoods in kinship care further. 


\section{References}

Ainsworth, F., \& Maluccio, A. N. (1998). Kinship care: False dawn or new hope? Australian Social Work, 51(4), 3-8. doi:10.1080/03124079808411238

Andresen, A. (2006). Hender små: bortsetting av barn i Norge 1900-1950 [Little hands: Placements of Children in Norway 1900-1950]. Bergen, Norway: Fagbokforlaget.

Archard, D. (1993). Children: Rights and childhood 2nd ed. London and New York: Routledge.

Bamberg, M. (1997). Positioning between structure and performance. Journal of narrative and life history, 7(1-4), 335-342.

Blaikie, N. (2007). Approaches to Social Enquiry. Cambridge, England: Polity press.

Broad, B. (2004). Kinship care for children in the UK: messages from research, lessons for policy and practice. European Journal of Social Work, 7(2), 211-227. doi:10.1080/1369145042000237463

Burgess, C., Rossvoll, F., Wallace, B., \& Daniel, B. (2010). 'It's just like another home, just another family, so it's nae different'. Children's voices in kinship care: a research study about the experience of children in kinship care in Scotland. Child \& Family Social Work, 15(3), 297-306. doi:10.1111/j.1365-2206.2009.00671.x

Cuddeback, G. S. (2004). Kinship family foster care: A methodological and substantive synthesis of research. Children and Youth Services Review, 26(7), 623-639. doi:10.1016/j.childyouth.2004.01.014

Del Valle, J. F., Lázaro-Visa, S., López, M., \& Bravo, A. (2011). Leaving family care: Transitions to adulthood from kinship care. Children and Youth Services Review, 33(12), 2475-2481.

Egelund, T. (1997). Beskyttelse af barndommen. Socialforvaltningers risikovurdering og indgreb. [The Protection of Childhood. Risk Assessment and Intervention of Child Protection Services ]. Copenhagen, Denmark: Hans Reitzels Forlag.

Egelund, T., Jakobsen, T. B., \& Steen, L. (2010). 'Det er jo min familie!' Beretninger fra børn og unge i slagtspleje ['But it's my family!' Stories from children and youth in kinship care]. (Report no. 10:34). Copenhagen, Denmark: SFI.

Gibbs, P., \& Müller, U. (2000). Kinship foster care moving to the mainstream: Controversy, policy, and outcomes. Adoption Quarterly, 4(2), 57-87. doi:10.1300/J145v04n02_04

Goffman, E. (1974). Frame Analysis: An essay on the Organization of Experience. New York, NY: Harper Colophon.

Gullestad, M. (2004). Imagined Childhoods: Modernity, Self and Childhood in Autobiographical Accounts. ISF Paper, (Institutt for samfunnsforskning), 12, Oslo, Norway. 
Gypen, L., Vanderfaeillie, J., De Mayer, S., Belenger, L., \& Van Holen, F. (2017). Outcomes of children who grew up in foster care: Systematic-Review. Children and Youth Services Review, 76, 74-83.

Harden, B. J., Clyman, R. B., Kriebel, D. K., \& Lyons, M. E. (2004). Kith and kin care: parental attitudes and resources of foster and relative caregivers. Children and Youth Services Review, 26(7), 657-671.

Hegar, R. L., \& Scannapieco, M. (1999). Kinship Foster Care: Policy, Practice, and Research. New York, NY: Oxford University Press.

Hessle, S., \& Vinnerljung, B. (1999). Child Welfare in Sweden - An overview. Stockholm studies in social work. (Vol. 15). Stockholm, Sweden: Stockholm University, Institute of social work.

Holtan, A., \& Thørnblad, R. (2009). Kinship foster parenting: gender, class and labour-force participation. European Journal of Social Work, 12(4), 465-478. doi:10.1080/13691450902840655

Jonsson, G. (1969). The social inheritance [Det sosiala arvet]. Stockholm, Sweden: Tidens förlag.

Järvinen, M., \& Mik-Meyer, N. (2003). At skabe en klient. Institutionelle identiteter i socialt arbejde [The making of Clients. Institutional Identities in Social Work]. Copenhagen, Denmark: Hans Reitzels Forlag

Kiraly, M., \& Humphreys, C. (2013). Perspectives From Young People about Family Contact in Kinship Care:"Don't Push Us_-Listen More”. Australian social work, 66(3), 314327. doi:10.1080/0312407X.2012.715658

Knudsen, L., \& Egelund, T. (2011). Effekter af slægtspleje: slægtsanbragte børn og unges udvikling sammenlignet med plejebørn fra traditionelle plejefamilier. [Effects of kinship care: children and youths development in kinship care comapred to nonkinship care ]. (Report nr. 11:20). Copenhagen, Denmark: SFI.

Lawler, S. (2002). Narrative in Social Research. In T. May (Ed.), Qualitative Research in Action (pp. 242-258). London, England: Sage.

Pupavac, V. (2001). Therapeutic governance: Psycho-social intervention and trauma risk management. Disasters, 25(4), 358-372.

Riessman, C. K. (2008). Narrative Methods for the Human Sciences. Los Angeles, CA: Sage.

Schutz, A. (1963). Concept and theory formation in the social sciences. In M. Natanson (Ed.), Philosophy of the social sciences (pp. 231-249). New York, NY: Random House.

Sinclair, I., Baker, C., Lee, J., \& Gibbs, I. (2007). The pursuit of permanence: A study of the English care system. London, England: Jessica Kingsley Publishers.

Skoglund, J., \& Thørnblad, R. (2017). Kinship care or upbringing by relatives? The need for 'new' understandings in research. European Journal of Social Work. doi:10.1080/13691457.2017.1364702 
Stein, M., \& Munro, E. R. (2008). Young People's Transitions from Care to Adulthood: International Research and Practice. London, England: Jessica Kingsley Publishers.

Thørnblad, R., \& Holtan, A. (2011). Oppvekst i slektsfosterhjem: unge voksne fosterbarns familieforståelser. [Growing up in kinship foster care: the family understanding of young adult foster children]. Tidsskrift for ungdomsforskning, 11(1), 49-67.

Winokur, M., Holtan, A., \& Batchelder, K. E. (2014). Kinship care for the safety, permanency, and well-being of children removed from the home for maltreatment. Cochrane Database of Systematic Reviews 2014(1). doi:10.1002/14651858.pub3. 